\title{
PENINGKATAN EFEKTIVITAS KERJA GURU MELALUI PENGUATAN KOMPETENSI PEDAGOGIK DAN IKLIM ORGANISASI
}

\author{
Sherly Maretha ${ }^{a)}$, Nandang Hidayat ${ }^{b)}$, Rais Hidayat ${ }^{\left.b^{*}\right)}$ \\ ${ }^{a)}$ SMP Citra Nusa, Bogor, Indonesia \\ ${ }^{b)}$ Universitas Pakuan, Bogor, Indonesia \\ *)e-mail korespondensi: rais.hidayat@unpak.ac.id
}

riwayat artikel : diterima: 06 November 2020; direvisi: 16 November 2020; disetujui: 06 Desember 2020

\begin{abstract}
Abstrak. Penelitian ini bertujuan untuk mengetahui secara empirik peningkatan efektivitas kerja guru. Sampel pada penelitian sebanyak 146 guru yang diambil menggunakan teknik proportional random sampling. Metode yang digunakan adalah metode korelasional. Pengujian hipotesis yang dilakukan dengan menggunakan analisis statistik parametrik dalam bentuk analisis regresi linier sederhana dan berganda, analisis korelasi sederhana dan berganda dengan taraf signifikansi $\alpha=0,05$. Penelitian ini menghasilkan tiga kesimpulan. Pertama, terdapat hubungan positif dan signifikan antara kompetensi pedagogik dengan efektivitas kerja guru dengan koefisien korelasi ryl=0,75. Kedua, terdapat hubungan positif dan signifikan antara iklim organisasi dengan efektivitas kerja guru dengan koefisien korelasi ry2 $=0,56$. Ketiga, terdapat hubungan positif dan signifikan antara kompetensi pedagogik dan iklim organisasi secara bersama-sama dengan efektivitas kerja guru dengan koefisien korelasi ry. $12=0,79$. Dapat disimpulkan bahwa efektivitas kerja guru dapat ditingkatkan melalui penguatan kompetensi pedagogik dan iklim organisasi.
\end{abstract}

Kata Kunci: efektivitas kerja guru; kompetensi pedagogik; iklim organisasi

\section{IMPROVING TEACHER WORK EFFECTIVENESS THROUGH PEDAGOGIC COMPETENCY STRENGTHENING AND ORGANIZATIONAL CLIMATE AT PRIVATE JUNIOR HIGH SCHOOLS IN CIBINONG, KABUPATEN BOGOR}

\begin{abstract}
This study aimed to determine empirically the enhancement of teacher work effectiveness. The sampling in the study was 146 teachers who were determined by using proportional technique. The method used was the correlation method. Hypothetical testing was carried out by using parametric statistical analysis in the form of simple and multiple linear regression analysis, where a significance level of $\alpha=0.05$. The research came up with three conclusions. Firstly, there was a positive and significant relationship between pedagogical competence and teacher work effectiveness where a random sampling correlation coefficient of ryl $=0.75$. Secondly, there was a positive and significant relationship between organizational climate and teacher work effectiveness where its correlation coefficient of ry $2=0.56$. Thirdly, there was a positive and significant relationship between pedagogic competence and organizational climate together with teacher work effectiveness where its correlation coefficient of ry.12 = 0.79. It could be concluded that teacher work effectiveness might be enhanced by strengthening the pedagogic competence and organizational climate.
\end{abstract}

Keywords: teacher work effectiveness; pedagogic competence; organizational climate

\section{PENDAHULUAN}

Tuntutan akan kualitas pendidikan selalu berimplikasi pada ketersediaan guru yang berkualitas yang dapat membantu memenuhi kebutuhan peserta didik dengan pengetahuan yang terus berkembang. Sedikitnya ada tiga faktor yang menyebabkan mutu pendidikan tidak mengalami peningkatan secara merata. Faktor pertama, kebijakan dan pennyelenggaraan pendidikan nasional yang menggunakan educational production function atau input-output analysis tidak dilaksanakan secara konsekuen. Faktor kedua, penyelenggaraan pendidikan nasional dilakukan secara birokratiksentralistik. Faktor ketiga, peran serta warga sekolah khususnya guru dan peran serta masyarakat khususnya orang tua peserta didik dalam penyelenggaraan pendidikan selama ini sangat minim. Tercapai atau tidaknya tujuan pendidikan sangat tergantung dari kinerja guru dalam menjalankan tugas dan fungsinya di sekolah. Undang-Undang Guru dan Dosen No. 14 tahun 2005 menjelaskan Guru adalah pendidik professional dengan tugas utama mendidik, mengajar, membimbing, mengarahkan, melatih, menilai dan mengevaluasi peserta didik pada pendidikan anak usia jalur pendidikan formal, pendidikan dasar, dan pendididkan menengah. Guru yang profesional, guru yang berkualitas adalah jaminannya. Tanpa perbaikan kualitas guru maka kualitas pendidikan akan tetap "jauh panggang dari api", akan tidak memadai.

Data UNESCO dalam Global Education Monitoring (GEM) Report 2016 memperlihatkan, pendidikan di Indonesia hanya menempati peringkat ke-10 dari 14 negara berkembang. Kualitas pendidikan di Indonesia masih jauh dari memadai. Hasil Uji Kompetensi Guru (UKG) tahun 2015, rata-rata nasional hanya 56,69 di bawah nilai standar 75. Dari 171,411 
guru jenjang SMP yang ada saat ini, masih terdapat 8,98 \% guru yang belum memenuhi syarat kualifikasi akademik, dan $72 \%$ guru belum memiliki sertifikat profesi. Fakta di tahun 2016, kualitas pendidikan di Indonesia berada di peringkat ke-62 dari 69 negara. Hal ini menjadi cermin konkret akan kualitas dan kuantitas guru di Indonesia. Maka harus ada langkah serius untuk membenahi kualitas guru. Karena nyatanya, tidak sedikit guru yang hari ini tetap saja menjalankan proses belajar-mengajar dengan pola "top-down". Guru seolah berada "di atas" dan siswa berada "di bawah", guru bertindak sebagai subjek dan siswa sebagai objek belajar.

\section{Efektvitas Kerja Guru}

Efektivitas kerja adalah hasil kerja yang terkait dengan tujuan organisasi seperti kualitas, efisiensi dan kriteria keefektifan lain yang dicapai selama periode tertentu melalui usaha yang membutuhkan kemampuan dan keterampilan serta pengalaman (Konopske, 2012:220). Blyth (2006: 26) menjelaskan bahwa efektif tidaknya suatu pekerjaan individu sangat terkait dengan peningkatan kualitas hidup individu tersebut. Thomas, Trams, Susanna, Linda, \& O’Hara yang membuktikan bahwa kepribadian atau personal yang terkontrol akan membentuk sikap dan mental yang lebih terarah dalam bekerja, dan hal tersebut akan sangat mendukung kerja individu dalam mencapai hasil kerja yang telah ditetapkan (O'Hara, 2005: 1-13).

Efektivitas kerja adalah hasil dari perilaku yang paling erat kaitannya dengan motivasi kerja internal. Motivasi kerja internal adalah perasaan harga diri untuk pencapaian pekerjaan yang telah dilakukan oleh mereka sendiri. Motivasi kerja internal adalah perasaan penghargaan diri dari melakukan pekerjaan itu sendiri (Champoux, 2015:149-150). Efektivitas kerja guru, dalam konsep ini, dipahami sebagai efektivitas pelaksanaan tugas mengajar (Dean, 2010:100-105)

Berdasarkan beberapa kajian teori di atas disintesiskan efektivitas kerja guru adalah ketepatan guru dalam melaksanakan tugas pekerjaannya sehingga tujuan pekerjaan dapat dicapai secara efektif. Indikator efektivitas kerja guru dalam penelitian ini adalah: 1) ketepatan perencanaan dengan tujuan, 2) ketepatan pengelolaan kelas, 3) kesesuaian proses pembelajaran, 4) Pelaksanaan evaluasi secara tepat, 5) pencapaian hasil kerja

\section{Kompetensi Pedagogik}

Kompetensi merupakan landasan dasar karakteristik orang dan mengidikasikan cara berprilaku dan berpikir, menyamankan sesuatu, dan mendukung untuk periode waktu cukup lama (Suwardji, 2012: 79-80). Kompetensi merupakan karakteristik utama yang dimiliki oleh orang yang paling sukses dalam setiap bidang profesi yang telah membantunya untuk berhasil (Kessler, 2011: 110-111). Broke dan Stone mendefinisikan kompetensi sebagai gambaran hakikat kualitatif dalam prilaku guru dan tenaga kependidikan yang merupakan perpaduan antara pengetahuan, keterampilan, nilai dan sikap yang direfleksikan dalam kebiasaan berpikir dan bertindak (Mulyasa, 2013: 88-90). Pentingnya membangun kualitas masyarakat Indonesia melalui pendidikan formal dan informal Tujuan proses pembelajaran dan kurikulum Guru adalah peserta didik mampu menguasai konsep ilmu pengetahuan dan sains, relevansinya dan aplikasinya dalam kehidupan sehari-hari dan dalam teknologi siswa harus mampu menerapkan berbagai konsep ilmu pengetahuan dan sains untuk memecahkan masalah-masalah dalam kehidupan sehari-hari dan teknologi secara ilmiah dan menguasai konsep-konsep untuk meningkatkan kesadaran akan kemajuan ilmu pengetahuan dan teknologi serta kelestarian lingkungan (Sunardi \& Suchyadi, 2020). Kompetensi merupakan seperangkat tindakan cerdas, penuh tanggung jawab yang dimiliki seseorang sebagai syarat untuk dianggap mampu oleh masyarakat dalam melaksanakan tugas-tugasnya dalam bidang pekerjaan tertentu (Umiarso, 2010:51-55). Kompetensi guru merupakan kemampuan seorang guru dalam melaksanakan kewajiban-kewajiban secara bertanggung jawab dan layak (Fathurrohman, 2004:89-90). Berdasarkan penjelasan di atas dapat dilihat secara jelas bahwa dari kemampuan, pemikiran, pengetahuan serta keterampilan seorang guru dalam proses mengajarnya akan terlihat pula pada kompetensi mengajarnya. Kompetensi tersebut akan terwujud dalam bentuk penguasaan pengetahuan dan profesional dalam menjalankan tugasnya. Hal ini senada dengan apa yang dikatakan Suparman, bahwa pengetahuan dan kemampuan guru secara tidak langsung terukur melalui apa-apa yang guru ajarkan (Suparman, 2010:60-65). Bantuan kepada guru agar guru dapat membantu para siswa belajar untuk menjadi lebih baik (Suchyadi, Karmila, \& Safitri, 2019). Berdasarkan kajian teori di atas dapat disintesiskan bahwa kompetensi pedagogik adalah kemampuan guru dalam mengelola pembelajaran sesuai dengan tugas dan peranannya yang berkenaan dengan seni mengajar dan mengelola peserta didik. Indikator kompetensi pedagogik dalam penelitian ini adalah (1) memahami peserta didik, (2) merancang pembelajaran, (3) melaksanakan pembelajaran, (4) mengevaluasi hasil pembelajaran, (5) mengembangkan potensi peserta didik

\section{Iklim Organisasi}

Iklim organisasi adalah nilai-nilai bersama, kepercayaan, norma, dan pemahaman anggota kelompok (Bridge, 2003:205-206). Menurut pendapat lain Iklim organisasi adalah lingkungan psikologis dan itu menunjukkan pada tingkat apa itu bermakna bagi karyawan kelompok (Terzi, 2000:100-101). Penjelasan lain mengenai iklim organisasi didefinisikan sebagai persepsi subjektif karyawan tentang bagaimana lingkungan kerja mereka memengaruhi mereka sebagai individu (Glisson, 2007:736-747). Iklim organisasi sebagai konstruk multidimensi yang mencakup berbagai evaluasi individu dari lingkungan kerja (Ashe, 1990:40-84). Iklim organisasi didefenisikan sebagai lingkungan kerja fisik dan non fisik yang mempengaruhi persepsi individu mengenai organisasi, dan mempengaruhi sifat dan perilaku individu itu sendiri dalam bekerja (Patras, 2017: 456). Iklim organisasi berdasarkan pola yang dirasakan dalam pengalaman dan perilaku spesifik 
orang-orang dalam organisasi (Holcombe, 2000: 21-36). Iklim organisasi didefinisikan sebagai persepsi karyawan dari lingkungan kerja. Adapun sikap terkait dalam pekerjaan dipengaruhi oleh individu dan prilaku. Indikator dari teori ini adalah (1) manajemen dan gaya kepemimpinan, (2) partisipasi dalam pengambilan keputusan, (3) menantang pekerjaan, (4) kebosanan dan prustasi, (5) tunjangan, (6) kebijakan personalia, (7) kondisi kerja, (8) tangga karir yang cocok (Adenike, 2011:151-165).

Berdasarkan kajian teori di atas dapat disintesiskan bahwa iklim organisasi adalah persepsi atau penilaian guru tentang keadaan lingkungan internal organisasi yang secara relatif terus berlangsung, dialami oleh anggota organisasi, dan mempengaruhi perilaku organisasi. Indikator iklim organisasi dalam penelitian ini adalah (1) tanggapan dan kepatuhan aturan-aturan dalam pekerjaan, (2) tanggung jawab, (3) dukungan positif yang dirasakan, (4) penghargaan terhadap prestasi, (5) pembagian tugas yang proposional, dan (6) loyalitas kelompok.

\section{METODE PENELITIAN}

Penelitian ini diarahkan untuk menganalisis dan mendeskripsikan data secara mendalam tentang korelasi antara kompetensi pedagogik dan iklim organisasi dengan efektivitas kerja guru SMP Swasta di Kecamatan Cibinong Kabupaten Bogor. Untuk memperoleh gambaran korelasi tersebut, maka jenis penelitian yang dipilih adalah penelitian kuantitatif dengan menggunakan metode penelitian korelasional. Penelitian ini dilaksanakan di SMP Swasta yang berada di wilayah Kecamatan Cibinong Kabupaten Bogor yang berjumlah 19 sekolah. Populasi pada penelitian ini bersifat homogen sebagaimana telah dilakukan pembatasan pada Bab I, adalah guru-guru (Guru Tetap Yayasan) SMP Swasta di Kecamatan Cibinong Kabupaten Bogor, dengan jumlah 230 orang guru swasta yang terdiri dari 19 SMP di Kecamatan Cibinong. Sampel dari penelitian ini adalah 146 responden, kemudian sampel ditentukan dengan menggunakan teknik proportional random sampling, yaitu pengambilan sampel pada tiap sekolah dilakukan melalui pengundian secara acak.

\section{HASIL DAN PEMBAHASAN}

\section{Pengujian Persyaratan Analisis}

\section{Uji Normalitas}

Hasil perhitungan normalitas galat baku taksiran (Y-Ŷ1) variabel efektivitas kerja guru atas varibel kompetensi pedagogik dengan menggunakan uji Liliefors diperoleh skor Lhitung maksimum sebesar 0,066, sementara Ltabel sebesar 0,074 dengan taraf signifikansi $\alpha=0,05$. Persyaratan normal adalah Lhitung $<$ Ltabel $(\alpha=0,05)$ dengan demikian galat baku taksiran $(\mathrm{Y}-\hat{\mathrm{Y}} 1)$ variabel efektivitas kerja guru atas variabel kompetensi pedagogik berasal dari populasi yang berdistribusi normal.

Hasil perhitungan normalitas galat baku taksiran $(\mathrm{Y}-\hat{\mathrm{Y}} 2)$ variabel efektivitas kerja guru atas varibel iklim organisasi dengan menggunakan uji Liliefors diperoleh skor Lhitung maksimum sebesar 0,049, sementara Ltabel sebesar 0,074

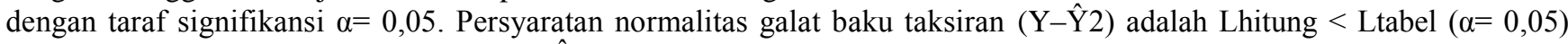
dengan demikian galat baku taksiran $(\mathrm{Y}-\hat{\mathrm{Y}} 2)$ variabel efektivitas kerja guru atas variabel iklim organisasi berasal dari populasi yang berdistribusi normal.

\section{Uji Homogenitas}

Homogenitas varians kelompok data variabel efektivitas kerja guru atas variabel kompetensi pedagogik diuji dengan persyaratan kelompok data homogen yaitu apabila $\chi 2$ hitung $<\chi 2$ tabel dengan signifikansi $\alpha=0,05$. Berdasarkan hasil perhitungan, diperoleh skor $\chi 2$ hitung sebesar 9,15 Sedangkan $\chi 2$ tabel $(\alpha=0,05)$ sebesar 16,92. Kesimpulannya varian skor data variabel efektivitas kerja guru atas kompetensi pedagogik berasal dari populasi yang homogen.

Homogenitas varians kelompok data variabel efektivitas kerja guru atas variabel iklim organisasi diuji dengan persyaratan kelompok data homogen yaitu apabila $\chi 2$ hitung $<\chi 2$ tabel dengan signifikansi 0,05 . Berdasarkan hasil perhitungan, diperoleh skor $\chi 2$ hitung sebesar 33,24 sedangkan $\chi 2$ tabel $(\alpha=0,05)$ sebesar 56,94. Kesimpulannya varian skor data variabel efektivitas kerja guru atas iklim organisasi berasal dari populasi yang homogen.

\section{Pengujian Hipotesis}

\section{Hubungan Antara Kompetensi Pedagogik Dengan Efektivitas Kerja Guru}

Dari perhitungan uji linieritas yang mana yang diuji adalah penyimpangan dari keadaan linear (deviation from linearity) diperoleh Fhitung sebesar 1,46, sedangkan Ftabel untuk dk pembilang $=8$ dan dk penyebut $=138$ dengan taraf signifikansi $\alpha=0,05$ sebesar 2,01. Hal ini berarti persyaratan signifikansi dimana Fhitung $<$ Ftabel dapat dipenuhi. Dengan demikian persamaan regresi $\hat{Y}=45,824+2,092 X 1$ adalah non signifikan, yang berarti regresi antara kedua variabel linear. Pengujian signifikansi korelasi sederhana diperoleh dengan menggunakan uji t dan mendapatkan hasil thitung sebesar 20,34, sedangkan untuk nilai ttabel dimana $\mathrm{dk}=144$ dengan taraf signifikansi sebesar 0,05 diperoleh nilai ttabel sebesar 1,65 yang berarti persyaratan signifikansi dimana thitung $>$ ttabel dapat dipenuhi. 
berarti terdapat hubungan positif yang signifikan antara variabel kompetensi pedagogik dengan variabel efektivitas kerja guru. Artinya, semakin tinggi kompetensi pedagogik, maka semakin tinggi pula efektivitas kerja guru. Sebaliknya, semakin rendah kompetensi pedagogik, maka semakin rendah pula efektivitas kerja guru yang diperlihatkan GTY SMP Swasta di Kecamatan Cibinong.

\section{Hubungan Iklim Organisasi Dengan Efektivitas Kerja Guru.}

Hasil analisis regresi linier sederhana antara variabel iklim organisasi dengan efektivitas kerja guru menghasilkan konstanta regresi sebesar 35,794 dan koefisien regresi sebesar 0,369, sehingga hubungan fungsional antara iklim organisasi dengan efektivitas kerja guru dapat dilihat dengan persamaan garis lurus $\hat{Y}=35,794+0,369 X 2$. Berdasarkan perhitungan uji signifikansi, maka diperoleh nilai Fhitung sebesar 66,34, sedangkan nilai Ftabel untuk dk pembilang $=1$ dan dk penyebut $=144$ dengan taraf signifikansi $\alpha=0,05$ sebesar 3,907. Hal ini berarti persyaratan signifikansi dimana Fhitung > Ftabel, dapat dipenuhi dan persamaan garis $\hat{\mathrm{Y}}=35,794+0,369 \mathrm{X} 2$ bersifat signifikan dan dapat digunakan untuk menjelaskan, memprediksi serta mendapatkan kesimpulan hubungan antara variabel iklim organisasi dengan efektivitas kerja guru.

Analisis korelasi sederhana antara variabel iklim organisasi dengan efektivitas kerja guru diperoleh dengan menggunakan rumus pearson product moment untuk menghitung koefisien korelasi (ry2). Kemudian korelasi ini akan diuji signifikansinya dengan menggunakan uji t, dimana thitung > ttabel. Dari hasil perhitungan diperoleh koefisien korelasi sederhana sebesar ry $2=0,56$. Interpretasi terhadap koefisien korelasi nilai $r$ menyatakan bahwa hubungan antara variabel iklim organisasi dengan variabel efektivitas kerja guru termasuk tingkat hubungan sedang (moderate). Berdasarkan hasil pengujian terhadap hipotesis kedua, maka ditemukan bahwa $\mathrm{H} 0$ ditolak dan menerima $\mathrm{H} 1$, yang berarti terdapat hubungan positif yang signifikan antara variabel iklim organisasi dengan variabel efektivitas kerja guru. Artinya, semakin tinggi semakin tinggi iklim organisasi maka semakin tinggi pula efektivitas kerja guru. Sebaliknya, semakin rendah iklim organisasi, maka semakin rendah pula efektivitas kerja guru yang diperlihatkan GTY SMP Swasta di Kecamatan Cibinong.

\section{Hubungan antara Kompetensi Pedagogik dan Iklim Organisasi Secara Bersama-Sama Dengan Variabel Efektivitas Kerja Guru}

Hasil analisis regresi linier berganda antara variabel kompetensi pedagogik dan iklim organisasi secara bersama-sama dengan variabel efektivitas kerja guru menghasilkan konstanta regresi a sebesar 22,36 dan koefisien regresi b1 sebesar 1,763 dan koefisien regresi b2 sebesar 0,18 , sehingga hubungan fungsional antara variabel kompetensi pedagogik dan iklim organisasi secara bersama-sama dengan variabel efektivitas kerja guru adalah persamaan garis lurus $\hat{Y}=22,36+1,763 \mathrm{X} 1+0,18 \mathrm{X} 2$.

Hasil perhitungan menunjukkan bahwa regresi ganda antara variabel kompetensi pedagogik dan iklim organisasi secara bersama-sama dengan variabel efektivitas kerja guru yang ditunjukkan dengan persamaan garis lurus $\hat{\mathrm{Y}}=22,36+$ 1,763X1 + 0,18X2 adalah signifikan. Dilihat dari hasil Fhitung sebesar 118,62 sedangkan untuk Ftabel dengan signifikansi sebesar 0,05 sebesar 3,06, maka dapat dinyatakan bahwa Fhitung > Ftabel. Dengan demikian maka persamaan regresi tersebut dapat dipergunakan untuk memprediksi variabel efektivitas kerja guru melalui variabel kompetensi pedagogik dan iklim organisasi secara bersama-sama, dimana setiap peningkatan satu unit variabel kompetensi pedagogik dan iklim organisasi akan meningkatkan efektivitas kerja guru guru secara bersama-sama sebesar 1,943 $(1,763+0,18)$.

\section{Korelasi Parsial}

Hasil analisis korelasi parsial hubungan antara variabel kompetensi pedagogik dengan efektivitas kerja guru dengan kontrol iklim organisasi menghasilkan koefisien korelasi parsial sebesar 0,67. Sedangkan signifikansi korelasi parsial dengan menggunakan uji $\mathrm{t}$ menghasilkan thitung sebesar 14,61. Pada taraf signifikansi $\alpha=0,05$, maka diperoleh ttabel sebesar 1,65. Hasil ini memenuhi kriteria signifikansi yaitu thitung > ttabel sehingga dapat disimpulkan bahwa korelasi parsial variabel kompetensi pedagogik dengan efektivitas kerja guru dengan kontrol iklim organisasi adalah signifikan.

Hasil analisis korelasi parsial hubungan antara iklim organisasi dengan efektivitas kerja guru dengan kontrol kompetensi pedagogik menghasilkan koefisien korelasi parsial sebesar 0,38 . Sedangkan signifikansi korelasi parsial dengan menggunakan uji $\mathrm{t}$ menghasilkan thitung sebesar 5,23. Pada taraf signifikansi $\alpha=0,05$, maka diperoleh ttabel sebesar 1,65. Hasil ini memenuhi kriteria signifikansi yaitu thitung > ttabel sehingga dapat disimpulkan bahwa korelasi parsial variabel iklim organisasi dengan efektivitas kerja guru dengan kontrol kompetensi pedagogik adalah signifikan. 


\section{Analisis SITOREM}

Tabel 1. Rekapitulasi hasil akhir analisis SITOREM.

\begin{tabular}{lll}
\hline \multicolumn{1}{c}{ Indicator in Initial State } & \multicolumn{1}{c}{ Efektivitas Kerja Guru } \\
After Weighting By expert & Indicator \\
\hline $\begin{array}{ll}\text { 1. Ketepatan perencanaan dengan } \\
\text { tujuan }\end{array}$ & $1^{\text {st }}$ kesesuaian proses pembelajaran $(23 \%)$ & 4,25 \\
2. Ketepatan pengelolaan kelas & $2^{\text {nd }}$ Pencapaian hasil kerja (22\%) & 4,25 \\
3. Kesesuaian proses pembelajaran & $3^{\text {rd }}$ Ketepatan perencanaan dengan tujuan & 3,64 \\
$\begin{array}{l}\text { 4. Pelaksanaan Evaluasi secara tepat } \\
\text { 5. Pencapaian hasil kerja }\end{array}$ & $4^{\text {th }}$ pelaksanaan evaluasi secara tepat (18\%) & 4,30 \\
& $5^{\text {th }}$ Ketepatan pengelolaan kelas (18\%) & 3,61 \\
\hline
\end{tabular}

\begin{tabular}{|c|c|c|}
\hline \multicolumn{3}{|c|}{ Kompetensi Pedagogik $\left(\mathrm{r}_{\mathrm{y} 1}=0,75\right)$} \\
\hline Indicator in Initial State & After Weighting By expert & Indicator Value \\
\hline 1. Memahami peserta didik & $1^{\text {st }}$ Mengembangkan potensi peserta & 0,69 \\
\hline 2. Merancang pembelajaran & didik $(23 \%)$ & 0,88 \\
\hline 3. Melaksanakan pembelajaran & $2^{\text {nd }}$ Melaksanakan pembelajaran $(22 \%)$ & 0,85 \\
\hline 4. Mengevaluasi pembelajaran & $3^{\text {rd }}$ Merancang pembelajaran $(20 \%)$ & \\
\hline 5. Mengembangkan potensi & $4^{\text {th }}$ Memahami peserta didik ( $\left.18 \%\right)$ & 0,87 \\
\hline peserta didik & $5^{\text {th }}$ Mengevaluasi pembelajaran (17\%) & 0,63 \\
\hline \multicolumn{3}{|c|}{ Iklim Organisasi $\left(\mathrm{r}_{\mathrm{y} 2}=0,56\right)$} \\
\hline Indicator in Initial State & After Weighting By expert & Indicator Value \\
\hline $\begin{array}{l}\text { 1. Tanggapan dan kepatuhan } \\
\text { aturan }\end{array}$ & $\begin{array}{l}1^{\mathrm{st}} \text { Tanggung jawab (20\%) } \\
2^{\text {nd }} \text { Dukungan positif yang dirasakan }\end{array}$ & 4,28 \\
\hline 2. Tanggung jawab & $(17 \%)$ & 4,15 \\
\hline $\begin{array}{l}\text { 3. Dukungan positif yang } \\
\text { dirasakan }\end{array}$ & $\begin{array}{l}3^{\text {rd }} \text { Penghargaan terhadap prestasi } \\
(17 \%)\end{array}$ & 3,47 \\
\hline $\begin{array}{l}\text { 4. Penghargaan terhadap } \\
\text { prestasi }\end{array}$ & $4^{\text {th }}$ Tanggapan dan kepatuhan aturan & 3,69 \\
\hline $\begin{array}{l}\text { 5. Pembagian tugas yang } \\
\text { proposional }\end{array}$ & $\begin{array}{l}5^{\text {th }} \text { Pembagian tugas yang proposional } \\
(15 \%)\end{array}$ & 4,21 \\
\hline 6. Loyalitas kelompok & $6^{\text {th }}$ Loyalitas kelompok $(14 \%)$ & 4,20 \\
\hline
\end{tabular}

\section{Pembahasan}

\section{Hubungan Kompetensi Pedagogik Dengan Efektivitas Kerja Guru}

Hubungan yang signifikan kedua variabel ini mengindikasikan bahwa, adanya pengaruh kompetensi pedagogik terhadap efektivitas kerja GTY SMP Swasta di Kecamatan Cibinong. Kompetensi pedagogik dan komitmen organisasi secara positif memiliki hubungan, yang mana kompetensi pedagogik telah memperlihatkan satu akibat berpengaruh nyata pada komitmen organisasi, artinya dengan kompetensi pedagogik guru yang baik maka guru dapat mengelola pembelajaran sesuai dengan tugas dan peranannya yang berkenaan dengan seni mengajar dan mengelola peserta didik, guru memerhatikan berbagai faktor yang dapat menghasilkan pembelajaran yang efektif seperti karakter dan gaya belajar peserta didik, merancang pembelajaran, melaksanakan pembelajaran, mengevaluasi hasil pembelajaran, dan pada akhirnya guru dapat mengembangkan potensi peserta didik.

Penelitian ini mendukung penelitian terdahulu yang dilakukan oleh Natanurlaela (2014:91-95) tentang pengaruh kompetensi pedagogik terhadap efektivitas kerja. Penelitian ini memberikan kesimpulan bahwa terdapat hubungan positif yang signifikan $(r=0,239 \mathrm{p}<0,05)$ antara komptenesi pedagogik dengan efektivitas kerja. Selain itu, Penelitian lain yang dilakukan oleh Zatmika (2019:95-97) tentang peningkatan efektivitas kerja guru melalui penguatan kepemimpinan transformasional dan kompetensi pedagogik penelitian dilakukan di MTs kota Sukabumi. Berdasarkan penelitian dapat disimpulkan bahwa efektivitas kerja guru dapat ditingkatkan melalui penguatan kepemimpinan transformasional dan kompetensi pedagogik sebesar 0,6743.

Penelitian ini dilakukan secara sistematis dan terstruktur. Pengumuplan data variabel efektivitas kerja guru dilakukan dengan menggunakan metode wawancara terstruktur. Wawancara terstruktur dilakukan oleh peneliti sendiri atau petugas yang sudah dilatih terlebih dahulu oleh peneliti. Peneliti atau petugas yang sudah dilatih menanyakan setiap indikator kepada responden sampai pewawancara yakin bahwa indikator tersebut terjadi, dilakukan, atau teramati yang juga didukung dengan bukti-bukti yang dapat diminta dengan santun kepada responden. Peneliti atau petugas yang sudah dilatih 
membubuhkan tanda centang pewawancara indikator tersebut terjadi, dilakukan, atau teramati, dengan ketentuan sebagai berikut: U= Unggul (Skor 5), jika 81\% - 100\% indikator terpenuhi, B = Baik (Skor 4), jika 61\% - 80\% indikator yang terpenuhi, $\mathrm{C}=$ Cukup (Skor 3), jika $41 \%$ - 60\% indikator yang terpenuhi, $\mathrm{R}=$ Rendah (Skor 2), jika $21 \%-40 \%$ indikator yang terpenuhi, dan $\mathrm{K}=$ Kritis (Skor 1), jika $0-20 \%$ indikator yang terpenuhi.

\section{Hubungan Antara Iklim Organisasi Dengan Efektivitas Kerja Guru}

Hubungan yang signifikan kedua variabel ini mengindikasikan bahwa adanya pengaruh iklim organisasi terhadap efektivitas kerja guru GTY SMP Swasta di Kecamatan Cibinong. Hal ini mengindikasikan juga bahwa Efektivitas kerja guru guru salah satunya dapat tercipta oleh iklim organisasi yang dirasakan oleh para guru. Iklim organisasi akan membentuk suasana yang ramah dan nyaman, hubungan yang didasarkan pada kepercayaan dan keterbukaan dan penciptaan kondisi yang kondusif untuk pembangunan sehingga membantu dalam mengontrol pengelolaan kelas dan terbentuknya komunikasi yang baik. Iklim organisasi akan membentuk kesatuan yang koheren dan tidak mengalami konflik yang signifikan yang dapat menghambat efektivitas kerja guru.

Penelitian ini mendukung penelitian terdahulu yang dilakukan oleh Rojai (2016:89-95) tentang hubungan antara iklim organisasi dan motivasi berprestasi dengan efektivitas kerja guru. Penelitian ini dilakukan di Lingkungan guru-guru Madrasah Tsanawiyah yang berstatus honorer. Hasil penelitian menunjukkan terdapat hubungan positif yang signifikan antara iklim organisasi dengan efektivitas kerja guru honorer MTS 57,51\%. Selain itu, hasil penelitian Zulaikha (2002:8184), tentang hubungan antara konsep diri dan iklim organisasi dengan efektivitas kerja guru. Penelitian ini menyimpulkan bahwa terdapat hubungan positif antara iklim organisasi dan konsep diri dengan efektivitas kerja guru, semakin tinggi iklim organisasi maka semakin tinggi pada efektivitas kerja guru tersebut. Dengan koofesien korelasi ry1: 0,777. Hal ini berarti iklim organisasi dapat berperan dalam meningkatkan efektivitas kerja guru. Dari hasil analisis SITOREM diperelihatkan juga indikator-indikator yang perlu diperbaiki lagi seperti indikator; tanggapan dan kepatuhan aturan dan penghargaan terhadap prestasi

\section{Hubungan Antara Variabel Kompetensi Pedagogik Dan Iklim Organisasi Secara Bersama-Sama Dengan Efektivitas Kerja Guru}

Hubungan yang signifikan variabel ini mengindikasikan bahwa, adanya pengaruh kompetensi pedagogik dan iklim organisasi secara bersama-sama terhadap efektivitas kerja guru GTY SMP Swasta di Kecamatan Cibinong. Berdasarkan pembahasan hasil penelitian di atas, dapat disimpulkan bahwa terdapat hubungan positif yang signifikan dengan kekuatan hubungan yang kuat antara variabel kompetensi pedagogik dan iklim organisasi secara bersama-sama dengan efektivitas kerja guru yang bermakna semakin tinggi kompetensi pedagogik dan iklim organisasi secara bersama-sama, maka semakin tinggi pula efektivitas kerja guru, sebaliknya semakin rendah kompetensi pedagogik dan iklim organisasi secara bersamasama, maka semakin rendah pula efektivitas kerja guru yang diperlihatkan GTY SMP Swasta di Kecamatan Cibinong.

Merujuk pada hasil pengujian hipotesis, dari besarnya koefisien korelai yang diperlihatkan, kekuatan hubungan yang paling besar terjadi ketika kedua variabel bebas secara bersama-sama mempengaruhi variabel terikat, dibandingkan dengan korelasi sederhana tiap variabel bebas dengan variabel terikat. Selain itu dapat dilihat dari hasil korelasi parsial yang memperlihatkan adanya kontribusi di antara variabel bebas untuk mempengaruhi variabel terikat dengan salah satu variabel bebas dikontrol. Dari hasil yang diperoleh dapat terlihat bahwa analisis korelasi parsial hubungan antara kompetensi pedagogik dengan efektivitas kerja guru dengan kontrol iklim organisasi menghasilkan koefisien korelasi parsial yang lebih besar dibandingkan dengan hasil analisis korelasi parsial hubungan antara iklim organisasi dengan efektivitas kerja guru dengan kontrol kompetensi pedagogik. Hal ini berarti bahwa kekuatan hubungan yang lebih besar diberikan oleh variabel kompetensi pedagogik dibaningkan dengan variabel iklim organisasi.

\section{SIMPULAN}

Berdasarkan hasil penelitian, disimpulkan bahwa efektivitas kerja guru dapat ditingkatkan melalui kompetensi pedagogik dan kepuasan kerja, baik secara terpisah maupun bersama-sama. Ditemukan terdapat hubungan positif yang sangat signifikan dengan kekuatan hubungan yang tinggi antara variabel kompetensi pedagogik dengan efektivitas kerja guru, terdapat hubungan positif yang sangat signifikan dengan kekuatan hubungan yang moderate antara variabel iklim organisasi dengan efektivitas kerja guru, dan terdapat hubungan positif yang sangat signifikan dengan kekuatan hubungan yang tinggi antara variabel kompetensi pedagogik (X1) dan iklim organisasi (X2) secara bersama-sama dengan efektivitas kerja guru (Y). Dari hasil analisi SITOREM ditemukan beberapa indikator yang perlu ditingkatkan seperti; mengevaluasi pembelajaran, mengembangkan potensi peserta didik, tanggapan dan kepatuhan aturan, penghargaan terhadap prestasi, ketepatan pengelolaan kelas, ketepatan perencanaan dengan tujuan. sedangkan beberapa indikator dapat dipertahankan seperti melaksanakan pembelajaran, merancang pembelajaran, memahami peserta didik, tanggung jawab, dukungan positif yang dirasakan, pembagian tugas yang proposional, loyalitas kelompok, kesesuaian proses pembelajaran, pencapaian hasil kerja, dan pelaksanaan evaluasi secara tepat. 


\section{REFERENSI}

Adenike, A. (2011). Organizational Climite as A Predictor of Employes Job Satisfacation: Evidence from Covenant University. Bussines Intelligence Journal, 14 No. 1, 151-165

B. Blyth. (2006). Corporate Document Service Incapacity Benefit reforms Pathways to Work Pilot Performance and Analysis Departement for Work and Pensions. Working Paper, No.26.

Bridge, B. (2003). Visionary Leadhership and effective management in education. Istanbul: Beyaz press. Visionary Leadhership and Effective Management in Education. Istanbul: Beyaz Press. 205-206

C. Glisson. (2007). Assessing and Changing Organizational Culture and Climate for Effective Services. Research on Social Work Practice. Assessing and Changing Organizational Culture and Climate for Effective Services. Research on Social Work Practice, 17, 736-747.

Champoux, J. E. (2015). Organizational Behavior: Integrating Individuals, Group, and Organization. Organizational Behavior: Integrating Individuals, Group, and Organization. 149-150

Fathurrohman, P. dan S. sutikno. (2004). Strategi Belajar Mengajar melalui Penanaman Konsep Umum\& Islami (Repika Adi). Bandung. 89-90

J.L, G., J.M., I., J.H., D., \& Konopske, R. (2012). Organization, Behavior, Processes (Vol. edisi 14). Chicago: Irwin. Pp. 220

James, L. R., \& Ashe, A. L. (1990). The meaning of organizations: the role of cognition and values. Organizational Climate and Culture. The Meaning of Organizations: The Role of Cognition and Values. Organizational Climate and Culture, 40-84

Mulyasa, E. (2013). Kurikulum Berbasis Kompetensi. Bandung: Remaja Rosdakarya. 88-90

Patras, Yuyun (2013). Hubungan Kepuasan Kerja Dan Iklim Organisasi Dengan Komitmen Organisasional Guru. Pedagogia, 9, 1,1-7.

Schillinger Dean. (2010:100-105). An Introduction to Effectiveness, Dissemination and Implementation Research. An Introduction to Effectiveness, Dissemination and Implementation Research.1

Schneider, Bowe, D., Ehrhart, M., \& Holcombe, K. (2000). Evolution of a Construct. In Handbook of Organizational Culture \& Climate. Pp 21-36 California: Sage Publications.

Suchyadi, Y., Karmila, N., \& Safitri, N. (2019). Kepuasan Kerja Guru Ditinjau Dari Peran Supervisi Kepala Sekolah Dasar Negeri Di Kecamatan Bogor Utara. JPPGuseda| Jurnal Pendidikan \& Pengajaran Guru Sekolah Dasar, 2(2), 91-94. https://doi.org/10.33751/jppguseda.v2i2.1453

Sunardi, O., \& Suchyadi, Y. (2020). Praktikum Sebagai Media Kompetensi Pedagogik Guru Sekolah Dasar. Jurnal Pendidikan Dan Pengajaran Guru Sekolah Dasar (JPPGuseda), O3(September), 124-127. https://doi.org/10.33751/jppguseda.v3i2.2737

Suparman. (2010). Gaya Mengajar yang Menyenangkan Siswa. Yogyakarta: Pinus Book Publisher. 60-65

Terzi, A. (2000). Organizational Culture. Ankara: Nobel Publishing House. Organizational Culture. Ankara: Nobel Publishing House. 100-101

Thomas, S. ., Susanna, T., A., L., \& O'Hara. (2005). Relation of Employee and Manager Emotional Intelegence to Job Satisfaction and performance. Journal of vocational behavior, 1-13

Umiarso. (2010). Manajemen Mutu Sekolah di Era Otonomi Pendidikan. Yogyakarta: Ircisod. 51-55 